\title{
Hubungan Berat Badan Bayi Lahir dengan Tingkat Robekan Perineum Pada Ibu Bersalin Normal di Rumah Sakit Pusri Palembang Tahun 2019
}

\section{Tirta Anggraini}

Akademi Kebidanan Budi Mulia Palembang

\section{Informasi Artikel :}

Diterima : 02 Mei 2020

Direvisi : 08 Mei 2020

Disetujui : 19 Mei 2020

*Korespondensi Penulis : tirtaanggraini1705@gmail.com

\begin{abstract}
A B S T R A K
Robekan perineum adalah luka pada perineum yang sering terjadi saat proses persalinan. Hal ini karena desakan kepala atau bagian tubuh janin secara tiba-tiba, sehingga kulit dan jaringan perineum robek. Berdasarkan data World Health Organization (WHO) pada tahun 2015 terjadi 2,7 juta kasus rupture perineum pada ibu bersalin. Berat bayi lahir merupakan faktor resiko yang meningkatkan kejadian perlukaan perineum. Semakin besar bayi yang dilahirkan beresiko terjadinya rupture perineum. Tujuan dari penelitian ini adalah untuk mengetahui Hubungan berat badan bayi terhadap robekan perineum pada ibu bersalin di Rumah Sakit Pusri Palembang Tahun 2019. Penelitian menggunakan survey analitik dengan pendekatan cross sectional. Populasi pada penelitian ini adalah semua ibu bersalin normal Pada November - 9 Desember 2019 di Rumah Sakit Pusri Palembang terkumpul sampel 38 orang responden. Pada analisa univariat dari 38 orang responden ibu bersalin normal yang mengalami tingkat robekan perineum normal lebih banyak yaitu 23 orang $(60,5 \%)$, di bandingkan dengan ibu bersalin yang mengalami tingkat robekan perineum tidak normal yaitu sebanyak 15 orang $(39,5 \%)$. Hasil uji statistik Chi-Square didapatkan nilai $p_{\text {_value }}=0,012<\alpha(0,05)$ yang berarti ada hubungan antara berat badan bayi lahir dengan tingkat robekan perineum normal dan tingkat robekan perineum tidak normal pada ibu bersalin normal di Rumah Sakit Pusri Palembang Tahun 2019.
\end{abstract}

\section{Kata kunci : Berat badan bayi, Tingkat Robekan Perineum}

\section{ABSTRACT}

The rupture of the perineum is a wound to the perineum which ofthen occurs during labor. This was due to sudden pressure of the head or fetal part of the body, so that the skin and perineal tissue is torn. Based on World Health Organization (WHO) data in the year 2015 occurred 2,7 million cases of rupture perineum in maternal mothers. Birth weght was a risk factor that increased the incidence of perineal injury. The larger baby was at risk of rupture of the perineum. The purpose of this study was to determine the relationship of infant weight to perineal rupture in maternal mothers at palembang pusri hospital in 2019. This study used an analytical survey with cross sectional approach. The population in this study were all normal maternal mothers on November December 9, 2019 at the pusri hospital Palembang. The sample was 38 respondents. In the univariate analysis of 38 respondents of normal maternal women who experienced a normal perennial rupture level were more than 23 people $(60,5 \%)$, compared to mothers who experienced abnormal perennial rupture level of 15 people (39,5\%). The result of Chi-Square statistic test obtained PValue $=0,012<\alpha(0,05)$ which means there was difference of mean of birth weight of baby born with normal perineum rupture 
level and level of perennial rupture in normal maternity mother at Pusri Palembang Hospital in 2019.

\section{Keywords : Infant weight, perineum rupture level}

\section{PENDAHULUAN}

Persalinan adalah suatu proses pengeluaran hasil konsepsi dari rahim ibu melalui jalan lahir atau jalan lain, yang kemudian janin dapat hidup ke dunia luar. Persalinan dimulai (inpartu) sejak uterus berkontraksi, sehingga menyebabkan perubahan pada serviks dan berakhir dengan lahirnya plasenta secara lengkap. ${ }^{1}$

Berdasarkan data World Health Organization (WHO) pada tahun 2015 terjadi 2,7 juta kasus rupture perineum pada ibu bersalin. Angka ini diperkirakan meningkat mencapai 6,3 juta pada tahun 2050 jika tidak mendapat perhatian dan penanganan yang lebih. ${ }^{2}$

Di Asia masalah robekan perineum juga merupakan masalah yang cukup banyak dalam masyarakat, 50\% dari kejadian robekan perineum di dunia terjadi di Asia. Prevalensi ibu bersalin yang mengalami robekan perineum di Indonesia pada golongan umur 25-30 tahun yaitu 24\%, dan pada ibu umur 32-39 tahun sebesar $62 \%$. $^{3}$

Faktor-faktor yang mempengaruhi persalinan yaitu adalah power, Power adalah tenaga yang mendorong keluar janin. Ada dua power yang bekerja dalam proses persalinan yaitu his dan tega mengejan ibu. His merupakan kontraksi uterus karena otot-otot polos bekerja dengan baik dan sempurna, pada saat kontrasi, otot-otot rahim menguncup sehingga menjadi lebih kecil mendorong janin dan kantong amnion kearah bawah rahim dan serviks. Sedangkan tenaga mengejan ibu adalah tenaga selain his yang membantu pengeluaran. ${ }^{1}$

Perdarahan postpartum menjadi penyebab utama $40 \%$ kematian ibu di Indonesia. Penyebab perdarahan utama adalah atonia uteri sedangkan ruptur perineum merupakan penyebab kedua yang hampir terjadi pada setiap persalinan pervaginam. Lapisan mukosa dan kulit perineum pada seorang ibu primipara mudah terjadi ruptur yang bisa menimbulkan perdarahan pervaginam. ${ }^{4}$

Menurut Survei Demografi dan Kesehatan Indonesia SDKI (2012), penyebab utama dari kematian ibu di Indonesia tersebut adalah perdarahan (27\%), eklampsi (23\%), infeksi (11\%), abortus (5\%), persalinan lama (5\%), emboli obstetrik (3\%), komplikasi puerperium (8\%), dan lain-lain (11\%). ${ }^{5}$
Di Sumatera Selatan, angka kejadian robekan perinium tahun 2010 mencapai $43 \%$ dari seluruh jumlah ibu post partum, diharapkan angka ini dapat menurun hingga 19\% pada tahun 2012. Penyebab terbesar kematian ibu yaitu perdarahan postpartum. Robekan jalan lahir merupakan penyebab kedua perdarahan setelah atonia uteri. Di Indonesia sekitar 40,8\% ibu bersalin mengalami perdarahan. ${ }^{5}$

Berat normal janin yang dapat dilahiran secara per vaginam yaitu antara $2500-4000$ gram, berat janin yang berlebih kadang menjadi kendala bagi para bidan yang akan menolong persalinan per vaginam. Rumus menghitung berat janin dalam uterus (rumus Lohnson) berat janin = (tinggi fundus uteri - 12) x 155 gram (jika kepala belum masuk PAP), berat janin = (tinggi fundus uteri - 11) x 155 gram (jika kepala sudah masuk PAP). ${ }^{6}$

Salah satu komplikasi yang dapat terjadi akibat ibu melahirkan bayi dengan berat badan berlebih yaitu adalah terjadinya robekan pada perineum. Robekan jalan lahir merupakan penyebab kedua dari perdarahan pasca persalinan, robekan perineum merupakan robekan yang terjadi sewaktu persalinan dan disebabkan oleh beberapa faktor antara lain posisi persalinan, cara meneran, pimpinan persalinan dan berat badan bayi baru lahir. ${ }^{7}$

Berdasarkan hasil penelitian Yuwida Enggar P di RB Harapan Bunda Surakarta pada tahun 2010 tentang Hubungan antara Berat Badan Bayi Baru Lahir dengan Kejadian Ruptur Perineum Pada Persalinan Normal di RB Harapan Bunda Surakarta, menunjukkan bahwa adanya Hubungan antara Berat Badan Bayi Baru Lahir dengan Kejadian Ruptur Perineum Pada Persalinan Normal. Mayoritas dengan berat badan bayi lahir 3000-3500 gr (46,3\%), dan mayoritas yang mengalami ruptur perineum yaitu ibu primipara sebanyak 52 orang $(77,6 \%) .^{5}$

Dari data yang di peroleh di Rumah Sakit Pusri Palembang pada bulan Januari-September 2019 ada 232 orang ibu bersalin normal. ${ }^{8}$

Dari latar belakang di atas maka peneliti tertarik untuk meneliti "Hubungan Berat Badan Bayi Lahir Dengan Tingkat Robekan Perineum Pada Ibu Bersalin Normal di Rumah Sakit Pusri Palembang Tahun 2019”. 


\section{METODE PENELITIAN}

Jenis penelitian ini termasuk kuantitatif bersifat analitik dengan menggunakan rancangan penelitian cross sectional merupakan suatu penelitian untuk mempelajari dinamika korelasi antara faktor-faktor dengan efek, dengan cara pendekatan, observasi atau pengumpulan data sekaligus pada suatu saat (point time approach). Dimana variabel independent berat bayi lahir serta variabel independent tingkat robekan perineum dan dikumpulkan sekaligus dalam waktu yang sama (Notoatmodjo, 2010)

Populasi dalam penelitian ini adalah ibu bersalin di Rumah Sakit Pusri Palembang pada bulan Oktober Tahun 2019 yang berjumlah 23 orang ibu bersalin. Sampel dalam penelitian ini adalah semua ibu bersalin yang mengalami tingkat robekan perineum di Rumah Sakit Pusri Palembang Tahun 2019 yang berjumlah 38 responden.

Teknik pengambilan sampel dalam penelitian ini dengan cara Purposive sampling, yaitu penentuan sampel dengan pertimbangan tertentu. Pemilihan sekelompok subjek dalam purposive sampling didasarkan atas ciri-ciri tertentu yang dipandang mempunyai sangkut paut yang erat dengan ciri-ciri populasi yang sudah diketahui sebelumnya, dengan kata lain unit yang dihubungi disesuaikan dengan kriteria-kriteria tertentu yang diterapkan berdasarkan tujuan penelitian.

Analisa univarat bertujuan untuk menggambarkan secara sistematis fakta atau karakteristik populasi tertentu atau bidang tertentu secara aktual dan cermat. Analisa yang dimaksud untuk mendeskripsikan masing-masing variabel independen yaitu pengetahuan dan sikap pada ibu nifas variabel dependen perawatan luka perineum

Analisa bivarat dilakukan berdasarkan uji chi-square untuk menemukan bentuk hubungan statistik antara variabel independen (Bayi Baru lahir) dan variabel dependen (Tingkat Robekan perineum). Hasil analisis bivarat merupakan hubungan antara masing-masing variabel dependen dan independen. Analisa bivariat dilakukan terhadap dua variabel yang diduga berhubungan. Untuk membuktikan apakah hipotesa diterima / ditolak, dengan menggunakan $\mathrm{x}^{2}$ (chi square).

\section{HASIL PENELITIAN}

\section{Analisis Univariat}

Analisis univariat yaitu analisis yang dilakukan terhadap satu variabel. Analisis ini dilakukan pada setiap variabel yang diteliti.

Tabel 1 Distribusi Frekuensi Dan Persentasi Tingkat Robekan Perineum Normal dan Tingkat Robekan Perineum tidak Normal di Rumah Sakit Pusri Palembang Tahun 2019

\begin{tabular}{rlcc}
\hline No & $\begin{array}{c}\text { Tingkat Robekan } \\
\text { Perineum }\end{array}$ & F & $\begin{array}{c}\text { Persentase } \\
(\%)\end{array}$ \\
\hline 1 & Derajat 1 & 7 & 18,4 \\
\hline 2 & Derajat 2 & 14 & 36,8 \\
\hline 3 & Derajat 3 & 9 & 23,7 \\
\hline 4 & Derajat 4 & 8 & 21,1 \\
\hline & Jumlah & $\mathbf{3 8}$ & $\mathbf{1 0 0}$ \\
\hline
\end{tabular}

Berdasarkan tabel 1 dapat dilihat dari 38 orang responden ibu bersalin normal yang mengalami tingkat robekan perineum derajat 1 sebanyak 7 orang $(18,4 \%)$, derajat 2 sebanyak 14 orang $(36,8 \%)$, derajat 3 sebanyak 9 orang $(23,7 \%)$, dan derajat 4 sebanyak 8 orang $(21,1 \%)$.

Tabel 2 Distribusi Frekuensi Dan Persentasi Berat Badan Bayi Lahir pada Ibu Bersalin Normal Di Rumah Sakit Pusri Palembang Tahun 2019

\begin{tabular}{|c|c|c|c|}
\hline $\begin{array}{l}\mathbf{N} \\
\mathbf{0}\end{array}$ & $\begin{array}{l}\text { Berat Badan Bayi } \\
\text { Lahir }\end{array}$ & $\mathbf{F}$ & $\begin{array}{c}\text { Persentase } \\
\quad(\%)\end{array}$ \\
\hline 1 & $\begin{array}{ll}\text { Berat Badan Lahir } \\
\text { Normal }\end{array}$ & 27 & 71,1 \\
\hline \multirow[t]{2}{*}{2} & $\begin{array}{l}\text { Berat Badan } \text { Bayi } \\
\text { Lahir Tidak Normal }\end{array}$ & 11 & 28,9 \\
\hline & Total & 8 & 100 \\
\hline
\end{tabular}

Berdasarkan tabel 2 dapat dilihat dari 38 bayi baru lahir, diantaranya $27(71,1 \%)$ bayi lahir dengan berat normal, dan 11 $(28,9 \%)$ bayi lahir dengan berat tidak normal.

\section{Analisis Bivariat}

Analisa bivariat dilakukan untuk mengatahui perbedaan antara dua variabel independen dan variabel dependen untuk membuktikan adanya perbedaan dua variabel 
yang disajikan dalam bentuk tabel dengan menggunakan uji Chi-Square pada variabel independen berat badan bayi lahir dan variabel dependen tingkat robekan perenium dimana pada kedua analisa data tersebut menggunakan derajat kepercayaan $95 \%$ (batas kemaknaan $\alpha 0,05$ ).

Jika p_value $<\alpha(0,05)$ artinya ada perbedaan yang bermakna antara variabel independen dan variabel dependen. Dengan demikian hipotesis yang menyatakan tidak ada perbedaan antara variabel independen dan variabel dependen tidak terbukti secara statistik. Jika $p_{-}$value $>\alpha(0,05)$ artinya tidak ada perbedaan yang bermakna antara variabel independen dan variabel dependen. Dengan demikian hipotesis yang menyatakan adanya perbedaan antara variabel independen dan variabel dependen tidak terbukti secara statistik.

Tabel 3 Hubungan Pengetahuan dengan Perawatan Luka Perineum di Rumah Sakit Rumah Sakit Pusri Palembang Tahun 2019

\begin{tabular}{|c|c|c|c|c|c|c|c|c|c|c|c|}
\hline \multirow{3}{*}{$\begin{array}{c}\text { Berat Badan } \\
\text { Bayi Lahir }\end{array}$} & \multicolumn{8}{|c|}{ Robekan Perineum } & \multirow{2}{*}{\multicolumn{2}{|c|}{ Total }} & \multirow{3}{*}{$P$ Value } \\
\hline & \multicolumn{2}{|c|}{ Derajat 1} & \multicolumn{2}{|c|}{ Derajat 2} & \multicolumn{2}{|c|}{ Derajat 3} & \multicolumn{2}{|c|}{ Derajat 4} & & & \\
\hline & $\mathbf{n}$ & $\%$ & n & $\%$ & $\mathbf{n}$ & $\%$ & $\mathbf{n}$ & $\%$ & $\mathbf{n}$ & $\%$ & \\
\hline BBL Normal & 5 & 18,5 & 12 & 44,4 & 4 & 14,8 & 6 & 22,2 & 27 & 100 & \\
\hline $\begin{array}{l}\text { BBL Tidak } \\
\text { Normal }\end{array}$ & 2 & 18,2 & 2 & 18,2 & 5 & 45,5 & 2 & 18,2 & 11 & 100 & 0,020 \\
\hline Total & 7 & 18,4 & 14 & 36,8 & 9 & 23,7 & 8 & 21,1 & 38 & 100 & \\
\hline
\end{tabular}

Hasil uji statistik Chi-Square didapatkan berat bayi lahir dengan tingkat robekan derajat 1 sebanyak $7(18,4 \%)$, derajat 2 sebanyak $14(36,8 \%)$, derajat 3 sebanyak 9 $(23,7 \%)$, derajat 4 sebanyak $8 \quad(21,1 \%)$. Dengan nilai $\mathrm{p}$-value $=0,020<\alpha(0,05)$ yang berarti ada hubungan antara berat badan bayi lahir dengan tingkat robekan perineum pada ibu bersalin normal. analisa data tersebut menggunakan derajat kepercayaan 95\% (batas kemaknaan $\alpha 0,05)$ dan diolah menggunakan Statistik Product For The Social Science (SPSS) versi 22. dan analisa bivariat. Uji statistik analisa bivariat menggunakan uji ChiSquare. Dimana pada

\section{PEMBAHASAN}

Penelitian ini dilakukan di Rumah Sakit Pusri palembang tahun 2019 . Yang menjadi sampel dalam penelitian ini ibu bersalin normal. Cara pengambilan Sampel dalam penelitian ini menggunakan tehnik Purposive sampling yang berjumlah 38 orang responden. Ibu bersalin yang mengalami robekan perineum derajat 1 sebanyak $7(18,4 \%)$, derajat 2 sebanyak $14(36,8 \%)$, derajat 3 sebanyak $9(23,7 \%)$, derajat 4 sebanyak 8 $(21,1 \%)$.

Jenis data penelitian adalah data primer, yaitu data yang diperoleh secara langsung dari responden di Rumah Sakit Pusri palembang Tahun 2019. Teknik pengumpulan data diperoleh melalui observasi melihat tingkat robekan ibu Selanjutnya data dipindahkan ke lembar checklist. Kemudian dilakukan analisa univariat

\section{Tingkat Robekan Perineum}

Dari hasil penelitian ini jumlah responden yang dijadikan sampel sebanyak 38 orang ibu yang mengalami tingkat robekan pada perineum derajat 1 sebanyak $7(18,4 \%)$, derajat 2 sebanyak $14(36,8 \%)$, derajat 3 sebanyak $9(23,7 \%)$, derajat 4 sebanyak 8 $(21,1 \%)$.

Berdasarkan data yang diperoleh dari Rumah Sakit Pusri Palembang pada bulan Januari-September Tahun 2019 terdapat 236 orang ibu bersalin normal, Sedangkan jumlah ibu bersalin pada 20 November-9 Desember di Rumah Sakit Pusri Palembang terdapat 38 orang ibu bersalin normal dimana ibu yang mengalami tingkat robekan perineum derajat 1 sebanyak $7(18,4 \%)$, derajat 2 sebanyak 14 $(36,8 \%)$, derajat 3 sebanyak $9(23,7 \%)$, derajat 4 sebanyak $8(21,1 \%)$.

Robekan perineum adalah robekan obsetrik yang terjadi pada daerah perineum akibat ketidakmampuan otot dan jaringan lunak pelvik untuk mengakomodasi lahirnya fetus. ${ }^{13}$

Robekan perineum terjadi hampir pada semua persalinan pertama dan tidak jarang pada persalinan berikutnya. Namun hal ini 
dapat dihindarkan atau dikurangi dengan menjaga jangan sampai dasar panggul dilalui oleh kepala janin dengan cepat. ${ }^{15}$

\section{Berat Badan Bayi Lahir Dengan Tingkat Robekan Perineum}

Hasil penelitian didapatkan bahwa berat badan bayi lahir dengan tingkat robekan derajat 1 sebanyak $7(18,4 \%)$, derajat 2 sebanyak $14(36,8 \%)$, derajat 3 sebanyak 9 $(23,7 \%)$, derajat 4 sebanyak $8 \quad(21,1 \%)$. robekan perineum tidak normal yaitu sebanyak $7(38,9 \%)$.

Berdasarkan hasil penelitian Yuwida Enggar P di RB Harapan Bunda Surakarta pada tahun 2010 tentang Hubungan antara Berat Badan Bayi Baru Lahir dengan Kejadian Ruptur Perineum Pada Persalinan Normal di RB Harapan Bunda Surakarta, menunjukkan bahwa adanya Hubungan antara Berat Badan Bayi Baru Lahir dengan Kejadian Ruptur Perineum Pada Persalinan Normal. Mayoritas dengan berat badan bayi lahir 3000-3500 gr $(46,3 \%)$, dan mayoritas yang mengalami ruptur perineum yaitu ibu primipara sebanyak 52 orang $(77,6 \%)$.

Berdasarkan hasil penelitian Stefania di RSU PKU Muhammadiyah Bantul Tahun 2016 tentang hubungan berat badan bayi lahir dengan derajat ruptur perineum pada ibu bersalin normal, terdapat 40 orang responden dan sebgian besar bayi lahir dengan berat normal 2500-4000 gram yaitu sebanyak 32 orang $(80 \%)$.

Dari hasil penelitian yang dilakukan Stefania terdapat 2 orang $(5 \%)$ berat bayi rendah dengan ruptur derajat I, $32(80 \%)$ berat bayi normal dengan frekuensi derajat luka perineum derajat I sebanyak 4 orang (10\%), derajat 2 sebanyak 23 orang $(57,5 \%)$, derajat 3 sebanyak 5 orang $(12,5 \%)$. Sedangkan bayi dengan berat lebih banyak 6 orang (15\%) dengan luka perineum derajat 3 sebanyak 5 orang $(12,5 \%)$ dan luka perineum derajat 4 sebanyak 1 orang $(2,5 \%)$.

Dari data tersebut dapat disimpulkan bahwa semakin besar bayi yaang dilahirkan makaa semakin besar pula peluang kejadian robekan perineum padaa persalinan normal.

Berdasarkan hasil penelitian yang dilakukan Septi arnilawti tentang Hubungan Berat Badan Bayi Lahir dengan tingkat robekan perineum pada ibu bersalin normal di puskesmas pembina palembang, dilihat dari 15 orang responden ibu bersalin normal yang mengalami tingkat robekan perineum normal lebih banyak yaitu sebanyak 8 orang $(53,3 \%)$ dengan berat lahir 2600-2900 gram, dibandingkan dengan ibu bersalin yang mengalami tingkat robekan perineum tidak normal yaitu sebanyak 7 orang $(46,7 \%)$ dengan berat lahir 3000-3700 gram.

Hasil uji statitik Mann-Whitny $U$ didapatkan nilai mean rank tingkat robekan perineum normal 4,50 dan tinglkat robekan perineum tidak normal 12,00. Didapatkan nilai $p$-value $=0,001<\alpha(0,05)$ yang berarti ada perbedaan rata-rata berat badan bayi lahir dengan tingkat robekan perineum normal dan tingkat robekan perineum tidak normal.

\section{Hubungan Berat Badan Bayi Lahir dengan Tingkat Robekan Perineum Pada Ibu Bersalin Normal di Rumah Sakit Pusri Palembang Tahun 2019.}

Berdasarkan hasil penelitian dapat dilihat dari 38 orang responden ibu bersalin normal yang mengalami tingkat robekan derajat 1 sebanyak $7(18,4 \%)$, derajat 2 sebanyak $14(36,8 \%)$, derajat 3 sebanyak 9 $(23,7 \%)$, derajat 4 sebanyak $8(21,1 \%)$.

Hasil uji statistik Chi-Square didapatkan berat bayi lahir dengan tingkat robekan derajat 1 sebanyak $7(18,4 \%)$, derajat 2 sebanyak $14(36,8 \%)$, derajat 3 sebanyak 9 $(23,7 \%)$, derajat 4 sebanyak $8 \quad(21,1 \%)$. Dengan nilai $p_{-}$value $=0,020<\alpha(0,05)$ yang berarti ada hubungan antara berat badan bayi lahir dengan tingkat robekan perineum pada ibu bersalin normal.

Berat badan lahir adalah berat badan bayi yang ditimbang 24 jam pertama kelahiran. Semakin besar bayi yang dilahirkan meningkatkan risiko terjadinya ruptur perineum. Bayi besar adalah bayi yang begitu lahir memiliki bobot lebih dari 4000 gram. Robekan perineum terjadi pada kelahiran dengan berat badan bayi baru lahir yang besar. Hal ini terjadi karena semakin besar berat badan bayi yang dilahirkan akan meningkatkan resiko terjadinya ruptur perineum karena perineum tidak cukup kuat menahan regangan kepala bayi dengan berat badan bayi yang besar, sehingga pada proses kelahiran bayi dengan berat berat badan bayi yang besar sering menyebabkan rupture. ${ }^{18}$

Berat badan lahir adalah berat badan bayi yang ditimbang 24 jam pertama kelahiran. Semakin besar berat bayi yang 
dilahirkan meningkatkan risiko terjadinya ruptur perineum.

Robekan perineum terjadi pada kelahiran dengan berat badan bayi yang besar. Hal ini terjadi karena semakin besar berat badan bayi yang dilahirkan akan meningkatkan risiko terjadinya ruptur perineum karena perineum tidak cukup kuat menahan regangan kepala bayi dengan berat badan bayi yang besar, sehingga pada proses kelahiran bayi dengan berat badan bayi lahir yang besar sering terjadi ruptur perineum. Kelebihan berat badan dapat disebabkan oleh beberapa hal diantaranya ibu menderita Diabetes Melitus, ibu yang memiliki riwayat melahirkan bayi besar, faktor genetik, pengaruh kecukupan gizi. Berat bayi lahir normal adalah sekitar 2500 sampai 4000 gram. ${ }^{10}$

Berat badan merupakan ukuran antropometri yang terpenting dan paling sering digunakan pada bayi baru lahir (neonatus). Berat badan digunakan untuk mendiagnosis bayi normal atau BBLR. Dikatakan BBLR apabila berat bayi-balita, berat bayi lahir di bawah 2500 gram atau di bawah 2,5 kg. Pada masa bayi-balita, berat badan dapat dipergunakan untuk melihat laju pertumbuhan fisik maupun status gizi, kecuali terdapat kelainan klinis seperti dehidrasi, asites, edema, dan adanya tumor. Di samping itu pula berat badan dapat dipergunakan sebagai dasar perhitungan dosis obat dan makanan. ${ }^{16}$

Berdasarkan Hasil uji statistik ChiSquare didapatkan nilai $p_{-}$value $=0,020<\alpha$ $(0,05)$ yang berarti ada hubungan antara berat badan bayi lahir dengan tingkat robekan perineum pada ibu bersalin di Rumah Sakit Pusri Palembang Tahun 2019.

Hasil penelitian ini sejalan dengan teori dan penelitian terdahulu yang telah dikemukakan diatas. Sehingga dapat disimpulkan bahwa berat badan bayi lahir dapat mempengaruhi tingkat robekan perineum pada ibu bersalin normal tersebut.

\section{KESIMPULAN}

Berdasarkan hasil penelitian disimpulkan bahwa ada hubungan antaara berat bayi lahir terhadap tingkat robekan perineum pada ibu bersaalin normal di Rumah sakit Pusri Palembang Tahun 2019 didapatkan nilai p-value $(0,020) \leq(0,05)$.

\section{DAFTAR PUSTAKA}

1. Rohani, 2014. Asuhan Kebidanan Pada Masa Persalinan. Jakarta: Salemba Medika

2. Hilmy.2012.http://stikesharapanmama.blogsp ot.com, diakses pada 2019

3. Champion Black, J.. 2011. Metode dan Masalah Penelitian Sosial, Bandung: Refika Aditama

4. Wiknjosastro, Hanifa. 2007. Ilmu Kebidanan. Jakarta: Yayasan Bina Pustaka Sarwono Prawirohardjo

5. Depkes RI. 2010. Profil kesehatan Indonesia. Jakarta: Depkes RI

6. Rochmah K . 2011. Asuhan Neonatus, Bayi, Dan Balita. Jakarta: EGC

7. Mochtar, Rustam. 2011. Sinopsis Obsterti. Jakarta: EGC

8. Profil RS PUSRI Palembang

9. Dewi, Vivian Nanny Lia. 2014. Asuhan Neonatus Bayi Dan Anak Balita. Jakarta: Salemba Medika

10.Abdul Bari, Saifuddin. 2008. Pelayanan kesehatan Maternal dan Neonatal. Jakarta: Bina Pustaka

11.Muslihatun, Wafi Nur. 2010. Asuhan Neonatus, Bayi Dan Balita. Yogyakarta: Fitramaya

12.Notoatmodjo. 2010. Metodologi Penelitian kesehata. Jakarta: PT. Rineka Cipta

13.Oxorn, Harry. 2010. Ilmu Kebidanan Patologi \& Fisiologi Persalinan. Yogyakarta: Yayasan Essentia Medica

14.Prawirohardjo, Sarwono. 2012. Ilmu Kebidanan. Jakarta: Bina Pustaka

15.Rukiyah, Ai Yeyeh, 2010: 361. Asuhan Kebidanan III (Nifas). Jakarta: Trans Info Media

16.Saleha, 2015:4.Asuhan Kebidanan Pada Ibu Nifas. Jakarta: Salemba Medika 
17.Sartika, 2014:57. Metode Penelitian Kebidanan dan Teknik Analisis Data. Jakarta: Salemba Medika

18.Sekartini, R. 2007. Penatalaksanaan Bayi Baru Lahir dan Pencegahan Komplikasi. Dikutip dari: www.mediaindonesia.co.id. Diakses pada 2017

19.Sugiyono. 2015. Metode Penelitian Pendidikan. Bandung: Alfabeta.

20.Sukarni I, Sudarti. 2014. Patologi Kehamilan, Persalinan, Nifas Dan Neonatus Resiko Tinggi. Yogyakarta: Nuha Medika

21.Yanti, 2011: 85.Asuhan Kebidanan Nifas. Bandung: Aditama

22.Yeti Anggraini, 2010: 1. Asuhan Kebidanan Pada Ibu Nifas. Jakarta: Salemba Medika 
